\title{
RAZVOJ BIBLIOMETRIJSKIH USLUGA SREDIŠNJE KNJIŽNICE FAKULTETA ELEKTROTEHNIKE I RAČUNARSTVA SVEUČILIŠTA U ZAGREBU
}

\author{
THE DEVELOPMENT OF BIBLIOMETRIC SERVICES \\ AT THE CENTRAL LIBRARY OF THE FACULTY \\ OF ELECTRICAL ENGINEERING AND COMPUTING \\ OF THE UNIVERSITY OF ZAGREB
}

\author{
Marko Tucaković \\ Fakultet elektrotehnike i računarstva \\ Sveučilište u Zagrebu \\ marko.tucakovic@fer.hr \\ Branka Marijanović \\ Fakultet elektrotehnike i računarstva \\ Sveučilište u Zagrebu \\ branka.marijanovic@fer.hr \\ Stjepan Šimara \\ Fakultet elektrotehnike i računarstva \\ Sveučilište u Zagrebu \\ stjepan.simara@fer.hr
}

UDK / UDC 005:001.8:027.7(497.5 Zagreb)

Stručni rad / Professional paper

Primljeno / Received: 11. 10. 2018.

Prihvaćeno / Accepted: 14. 12. 2018.

\section{Sažetak}

Cilj. Cilj je ovog rada dati prikaz razvoja bibliometrijskih usluga Središnje knjižnice FER-a od samih početaka do danas. Usporedno je dan pregled osnovnih propisa i zakona relevantnih za bibliometrijske postupke, kako bi se ukazalo na značajan doprinos koji

Vjesnik bibliotekara Hrvatske 62, 1(2019), 341-362

ISSN 0507-1925

(C) VBH 2018. 
knjižničari mogu dati procesu evaluiranja znanstvenog i akademskog napredovanja. Također, cilj je rada dati kritički osvrt i ukazati na određene nedostatke pravnog sustava koji kreira politiku uvjeta napredovanja u hrvatskoj akademskoj zajednici. Konačna namjera autora bila je ponuditi smjernice za transparentan, kvalitativan i neovisan sustav procjene znanstvene uspješnosti na Fakultetu elektrotehnike i računarstva Sveučilišta u Zagrebu.

Pristup. U radu je dan kraći osvrt na povijest razvoja bibliometrije, s posebnim osvrtom na tehničke znanosti i zakonske propise na razini Republike Hrvatske, pa tako i Fakulteta elektrotehnike i računarstva u Zagrebu. U radu je detaljno prikazan razvoj bibliometrijskih usluga Središnje knjižnice FER-a.

Rezultati. Rad prikazuje kako se uspostavom i razvojem nove usluge Središnja knjižnica FER-a etablirala na razini matične ustanove, ali i u akademskoj zajednici. Središnja knjižnica, kao mjerodavna služba Fakulteta, utkana je i u same propise Fakulteta kao obvezujući i neizostavan čimbenik procesa znanstvenog i nastavnog napredovanja. Radom se također potiče dijalog kako bi se zakonske regulative mogle unaprijediti s obzirom na određene manjkavosti na koje autori ukazuju u ovom radu.

Originalnost. Pregledom širokog spektra zakonodavnih akata dan je uvid u značaj i inkorporiranost knjižnične djelatnosti u sustav znanstvenih napredovanja na temelju primjera dobre prakse, a ukazuje se na mogućnosti koje stoje pred zajednicom visokoškolskih knjižničara. U radu je na detaljan način opisana struktura djelovanja radnih tijela Fakulteta elektrotehnike i računarstva pri evaluaciji znanstvene uspješnosti znanstveno-nastavnog osoblja.

Ključne riječi: bibliometrija, izbori u znanstveno-nastavna zvanja, Središnja knjižnica FER-a, visokoškolske knjižnice, znanstvena produktivnost

\begin{abstract}
Purpose. The purpose of this paper is to give an overview of the development of the Faculty of Electrical Engineering and Computing of the University of Zagreb (FER) Central Library bibliometric services from the beginning until today. Simultaneously, a review of basic regulations and laws relevant to bibliometric procedures is presented, in order to point out the significant contribution that librarians can make to the process of evaluating scientific and academic advancement. Furthermore, the purpose of the paper is to give a critical analysis and to point to certain shortcomings of the Croatian legal system that creates the policy of academic advancement requirements in the academic community. The overall purpose is to set the foundations for a transparent, qualitative and independent system of scientific evaluation in the Republic of Croatia.
\end{abstract}

Approach. The paper gives an overview of the history of bibliometrics development, with special emphasis on technical sciences, legal regulations of the Republic of Croatia, as well as the Faculty of Electrical Engineering and Computing in Zagreb. The 
paper presents a detailed description of the development of bibliometric services of the FER Central Library.

Findings. The paper shows how by establishing and developing the bibliometric services the Central Library has positioned itself as a significant unit at its parent institution, as well as in the Croatian academic community. As a competent Faculty organizational unit, the Library is now embedded into Faculty's regulations as a necessary and indispensable component in the process of scientific and academic advancement. The paper also initiates a dialogue to enhance the legal regulations, considering certain deficiencies to which authors point in this paper.

Originality. By reviewing a broad spectrum of legislative acts, the paper gives an insight into the status and incorporation of librarianship into the system of scientific advancement requirements based on good practice and illustrates the opportunities available to the community of academic librarians. The paper describes in detail the structure and activities of the Faculty of Electrical Engineering and Computing boards and committees in evaluating the scientific performance of the scientific and teaching staff.

Keywords: bibliometrics, election to academic-teaching positions, FER Central Library, higher education libraries, scientific productivity

\section{Uvod}

Visokoškolske knjižnice kao knjižnice u sastavu imaju ulogu potpomagati obrazovni, stručni i znanstveni rad matične ustanove. Kao korisnike visokoškolskih knjižnica možemo izdvojiti prvenstveno studente te znanstveno-nastavno osoblje. Važno je naglasiti i suradnju s ostalim knjižnicama u sustavu visokog obrazovanja, primjerice visokoškolskim knjižnicama iz područja tehničkih znanosti, matičnom službom za visokoškolske knjižnice pri Nacionalnoj i sveučilišnoj knjižnici u Zagrebu te školstvom i privredom općenito, jer se time raspon korisnika i usluga koje visokoškolski knjižničari pružaju znatno širi. Među spomenutim korisnicima, znanstveno-nastavno osoblje čini primarni segment na temelju kojeg se planiraju i razvijaju usluge koje visokoškolska knjižnica pruža. No kako se razvojem informacijskih tehnologija i sama uloga i poslovanje knjižnica mijenja, a uvođenje bolonjskog procesa u sustav visokog obrazovanja donijelo je promjene i u visokoškolske knjižnice, knjižničari su se polako počeli afirmirati razvojem postojećih usluga i modela poslovanja. Prema tome, usluge visokoškolskih knjižnica zasigurno idu ukorak s razvojem informacijsko-komunikacijske tehnologije, a prvenstveno se fokusiraju na prikupljanje, obradu i pohranjivanje informacija u svim formatima, osiguravanje pristupa izvorima informacija, poučavanje $u$ informacijskoj pismenosti te na praćenje i evaluaciju znanstvene produktivnosti matične ustanove. 
Bibliometrija od prvih pokušaja 1990-ih godina nadalje zauzima sve veći prostor unutar područja poslovanja visokoškolskih knjižnica, a tek u posljednjih nekoliko godina knjižničari polako postaju uključeni u sustav procjene znanstvenog rada znanstvenika te se svojim kompetencijama pozicioniraju kao stručnjaci u tom području.

\section{Tehničke znanosti}

Tehničke znanosti prvenstveno obilježava njihova primjenjivost, vrlo širok raspon te različitost područja djelovanja koja počivaju na zajedničkim temeljima - prirodnim znanostima. Teorijska osnova i znanja na kojima se tehnika temelji, „kao i djelatnost usmjerena na stjecanje tih znanja i spoznaja, izvodi se uz pomoć istraživanja, a uključuje i širenje spoznaja kroz izvještavanje i obrazovanje“, razvojem umijeća i vještina, što rezultira njezinom primjenjivošću u svakodnevnom životu.

Budući da pri osnutku Sveučilišta u Zagrebu 1874. godine tehničke znanosti nisu bile zastupljene, jedina institucija koja je okupljala tu struku bilo je Društvo inženjera i arhitekata u Hrvatskoj i Slavoniji. To društvo možemo nazvati kolijevkom tehničkih znanosti u Hrvatskoj, budući da je upravo iz redova njegova članstva potekla zamisao o osnivanju visoke tehničke škole u Zagrebu s inženjerskim odsjekom. Tehnička visoka škola osnovana je 1918. godine, a 1926. godine proglašena je Tehničkim fakultetom Sveučilišta u Zagrebu. Godine 1956. iz Tehničkog fakulteta nastala su 4 nova fakulteta, a među njima i Elektrotehnički fakultet (ETF), odnosno današnji Fakultet elektrotehnike i računarstva (FER).

Iako su se od osnutka Tehničkog fakulteta, koji gledamo kao temelj tehničkih znanosti, dogodile razne tehnološke promjene, osnovna načela tehničkih znanosti ostala su ista: izumi i vještine temeljeni na prirodnim znanostima, uz primjenu informacijske tehnologije.

Sektor elektrotehnike i računarstva područje je tehničkih znanosti koje je prisutno u svim granama gospodarstva, a temelji se na novoj generaciji infrastrukture. Tako i područje informacijsko-komunikacijske tehnologije podupire razvoj gotovo svih djelatnosti, a ne samo usko definiranih djelatnosti koje se bave računarstvom ili elektrotehnikom.

\section{O bibliometriji}

Iako su se bibliometrijske metode počele značajnije razvijati i primjenjivati s pojavom informacijskih tehnologija, korijene bibliometrije u smislu statističkih analiza literaturei pisane riječinalazimonapočetku dvadesetog stoljeća. Kakonavodi Krajna , prvi rad iz područja bibliometrije objavljen je 1917. godine, a Paul Otlet u svojoj knjizi Traite de documentation iz 1934. godine cijelo je jed- 
no poglavlje naslovio Le livre et la mesure - Bibliometrie. Alan Pritchard 1969. godine definirao je bibliometriju kao primjenu matematičkih i statističkih metoda na knjige i ostale medije u znanstvenom komuniciranju te se time smatra da je on uveo pojam bibliometrije.

Zanimanje za bibliometriju povećalo se 1970-ih zbog novih spoznaja o potrebi razmjene znanja i racionalizacije dokumentacijskih službi. Bibliometrija je uvedena kao predmet na mnogim studijima knjižničarstva i informacijskih znanosti u svijetu, dok se na studije bibliotekarstva i informacijskih znanosti u Hrvatskoj uvodi tek nakon 2000. godine. Kao kvantitativno vrednovanje rezultata znanstvenog rada, bibliometrija se javlja u pojedinim hrvatskim visokoškolskim knjižnicama 1990-ih godina, kao posljedica tehnoloških promjena u znanstvenom izdavaštvu koje su dovele do pojave elektroničkih znanstvenih časopisa. Međutim proći će još dugi niz godina do priznavanja hrvatskih knjižničara kao stručnjaka za bibliometriju te uključivanja visokoškolskih knjižnica u sustav vrednovanja znanstvene uspješnosti.

Ovdje je potrebno naglasiti ulogu citatne analize kao jedne od (analitičkih) metoda u bibliometriji - na njezinim se dosezima zapravo i zbiva prethodno naznačeni uvećani udio bibliometrije u poslovanju knjižnica - a za koju nam se nudi i odgovorno je samo jedno ime: Eugene Garfield. Izum citatnog kazala koji se njemu pripisuje, a izrastao je na onom bibliografskom, načelno je otvorio perspektivu jedne nove mjere, temeljene na uvidu u literarni model znanosti i razumijevanju citata kao svojevrsnog indeksa znanstvenog zajedništva - iako se zbiva na publicističkoj razini kao sveprisutno dostupna i mjerljiva referenca, na temelju fenomenološkog uvida kako „gotovo svi radovi sadrže citate“. Nadalje, u personificiranom obliku na semantičkoj razini, Garfield ističe kako citatno indeksiranje eksplicitno otkriva intelektualne odnose između stare i nove literature, kao i korak dalje, na razini znanja o znanju, u jednoj od njegovih podjela na tacitno ili eksplicitno. Na svemu tome, zapravo, nastala su citatna kazala, u brižnim selekcijskim procesima, što integrirajućom naravi citata rezultira osnovnom (citatnom) podjelom publicirajuće znanosti, predstavljene u vidu produkta kao što su SCI (Science Citation Index), SSCI (Social Sciences Citation Index) i AHCI (Arts \& Humanities Citation Index). Citatna analiza, kao primjena statističkih metoda unutar citatnih kazala i kao alat za procjenjivanje znanstvene uspješnosti (engl. science management tool), omogućila je da se u jednom od segmenata svoje primjene „koristi kao podrška izazovu donošenja formalne pravne odluke o znanstvenom napredovanju“ te da se etablira u sustavima vrednovanja znanstvene uspješnosti - a na toj podlozi djeluju svi pravilnici o kojima će biti nešto više riječi u nastavku. No potrebno je naglasiti da je to područje primjene zadobila isključivo primarnim uvidom, kao svojevrsnim „metajamstvom“, stoga što citiranost „reflektira vrednovanje kvalitete znanstvenog rada", odnosno samo stoga što istraživanja ukazuju da je ono 
u strogoj korelaciji sa znanstvenim vrednovanjem jer postoji „snažna, pozitivna korelacija između broja citata i prosudbi znanstvenoistraživačke zajednice“. Čini se da bez tog osnovnog sastojka semantičke ispravnosti za postupke vrednovanja nikakva kasnija iskoristivost ne bi bila moguća, ili pak bi, ali na „sumnjivim temeljima“. Drugim riječima, to je osnova svih evaluacijskih pokušaja temeljenih na citatu i njegovim inačicama.

Vidljivo je kako bibliometrija i citatna analiza (na podlozi citatnih kazala) tvore čvrstu i nedjeljivu isprepletenost, primarno zajedništvo usmjereno prema djelotvornom metričkom cilju. Ili kako nam to kazuje Garfield u inicijalnom osvrtu na vlastito djelo i u pogledu perspektiva, citatno kazalo ima „golemi utjecaj i na područje bibliometrije i upotrebu citatnih podataka unutar tog područja“ - primarni faktor odjeka.

\section{Bibliometrija u okviru zakonskih propisa Republike Hrvatske i FER-a}

Važan čimbenik u prosudbi znanstvene uspješnosti te znanstvenog i akademskog napredovanja u Hrvatskoj jest broj objavljenih radova, citiranost radova i ostali kvantitativni pokazatelji. Pritom se posebno vrednuju radovi objavljeni u publikacijama koje su indeksirane u nekim od međunarodnih indeksnih publikacija, odnosno bibliografskim bazama podataka.

Zakonodavni okvir u području znanosti i visokog obrazovanja u nadležnosti je rada Agencije za znanost i visoko obrazovanje, koja surađuje s matičnim odborima određenih znanstvenih polja unutar pojedinih znanstvenih područja te visokoškolskim institucijama. Matični odbori djeluju pri Nacionalnom vijeću za znanost, visoko obrazovanje i tehnološki razvoj. Agencija za znanost i visoko obrazovanje imenuje članove matičnih odbora iz redova vrsnih znanstvenika i članova akademske zajednice. Matični odbor za polja elektrotehnike i računarstva broji ukupno jedanaest članova, od kojih je pet iz redova profesora Fakulteta elektrotehnike i računarstva Sveučilišta u Zagrebu (predsjednik matičnog odbora, potpredsjednik za znanost, potpredsjednik za visoko obrazovanje te dva redovna člana).

Znanstvena politika Fakulteta bazira se na skupu pravnih propisa koji donose okvire djelovanja, pravila i načela sa svrhom reguliranja aktivnosti Fakulteta. Tako pri Fakultetu djeluje Odbor za izbore u zvanja kao radno tijelo Fakultetskog vijeća koje sudjeluje u postupku izbora u znanstvena zvanja.

Postupak izbora u znanstveno-nastavna zvanja odvija se tako da kandidat podnese osobni zahtjev (podnesak) za izbor u znanstveno zvanje ovlaštenoj znanstvenoj organizaciji zajedno s dokazima o ispunjavanju uvjeta za izbor u određeno zvanje. Znanstvena organizacija također može podnijeti zahtjev za izbor u zvanje u ime određenog kandidata. Na temelju takva podneska kojim se traži izbor u 
znanstveno zvanje te dokaza o ispunjavanju uvjeta, matični odbor i povjerenstvo za ocjenu rada znanstvenika ocjenjuju sveukupnu znanstvenu djelatnost pristupni$\mathrm{ka}$, vodeći računa o posebnostima pojedinih znanstvenih i umjetničkih područja te pojedinih znanstvenih polja i interdisciplinarnih područja, kako je i naglašeno u Pročišćenom tekstu Zakona o znanstvenoj djelatnosti i visokom obrazovanju. Povjerenstvo prethodno raspravlja o pristiglim prijedlozima te podnosi konačni prijedlog. Odlukom Fakultetskog vijeća pristupnik se izabire u više zvanje. Ovdje je važno naglasiti relevantne i trenutno važeće akte za postupak izbora u zvanja:

- Odluka o nužnim uvjetima za ocjenu nastavne i znanstveno-stručne djelatnosti u postupku izbora u znanstveno-nastavna zvanja (2017)

- Statut FER-a

- Pravilnik o radu Središnje knjižnice

- Zakon o znanstvenoj djelatnosti i visokom obrazovanju (2013)

- Pročišćeni tekst Zakona o znanstvenoj djelatnosti i visokom obrazovanju

- Statut Sveučilišta u Zagrebu

- Pravilnik o uvjetima za izbor u znanstvena zvanja (2017)

- Pravilnik o uvjetima za izbor u znanstvena zvanja

- Pravilnik o uvjetima za izbor u znanstvena zvanja (dopuna)

- Dodatne upute Matičnog odbora za pisanje izvješća za znanstvena zvanja

- Obvezni sadržaj podneska za izbor u znanstveno zvanje na osobni zahtjev ili po zahtjevu znanstvene organizacije

- Odluka o nužnim uvjetima za ocjenu nastavne i stručne djelatnosti u postupku izbora u znanstveno-nastavna zvanja

- Odluka o nužnim uvjetima za ocjenu nastavne i stručne djelatnosti u postupku izbora u nastavna zvanja (NN 13/2012)

- Pravilnik o uvjetima FER-a za izbore u naslovna znanstveno-nastavna zvanja

- Odluka o obliku i načinu provedbe nastupnog predavanja

- Pravilnik o znanstvenim i umjetničkim područjima, poljima i granama

- Uvjeti iz odluke Vijeća tehničkog područja (minimalno vrijeme između izbora).

Fakultet elektrotehnike i računarstva svake godine dodjeljuje više različitih nagrada svojim studentima i zaposlenicima. Sljedeći dokumenti uzimaju se u obzir pri dodjeljivanju nagrada studentima i djelatnicima Fakulteta:

- Pravilnik o nagradi za znanost

- Naputak o primjeni Pravilnika o nagradi za znanost

- Naputak o primjeni Pravilnika o nagradi „Josip Lončar“ na Sveučilištu u Zagrebu, FER - Srebrna plaketa. 
Prema Naputku o primjeni Pravilnika o nagradi „Josip Lončar“ na Sveučilištu u Zagrebu, Fakultetu elektrotehnike i računarstva, Središnja knjižnica dužna je pripremiti bibliometrijske pokazatelje za radove kandidata za nagradu Srebrna plaketa „Josip Lončar“. Ta nagrada dodjeljuje se doktorima znanosti za naročito uspješne doktorske disertacije te nastavnicima i suradnicima za trajniji doprinos nastavi, znanosti i struci. Naputkom su specificirani pokazatelji koji se uzimaju u obzir prilikom procjene kandidata. Uz recenziju mentora (povjerenstva za ocjenu/obranu), u obzir se uzimaju temeljni bibliometrijski pokazatelji o radovima predloženika koji uključuju broj objavljenih radova, broj autora na radu i to je li predloženik prvi autor, broj citata, čimbenik odjeka (engl. impact factor) časopisa u kojima ima objavljene radove te mjesto (rang) časopisa u području u kojem se časopis referira.

Središnja knjižnica formalno je uključena i ima funkciju u sklopu procesa izbora u zvanja i postupka dodjeljivanja nagrada zaposlenicima, a važećim propisima to je i potkrijepljeno. Sam Pravilnik o radu Središnje knjižnice u članku 8 navodi kako Knjižnica za svoje korisnike pruža bibliometrijske usluge kao što su izdavanje potvrda o indeksiranosti i citiranosti radova te potvrda o metričkim pokazateljima časopisa za potrebe znanstveno-nastavnoga napredovanja, doktorskoga studija, stručnoga napredovanja, znanstvenih projekata i slično. Uz to, Pravilnik spominje analizu znanstvene produktivnosti ustanove, zavoda i skupina znanstvenika kao uslugu Središnje knjižnice.

Također, Obvezni sadržaj podneska za izbor u znanstveno zvanje na osobni zahtjev ili po zahtjevu znanstvene organizacije navodi podatke o radovima na temelju kojih pristupnik ispunjava uvjete za izbor u znanstveno zvanje, navodeći da knjižnice javnih visokoškolskih i znanstvenih ustanova izdaju potvrde o zastupljenosti (indeksiranosti) časopisa u bazama podataka propisanim Pravilnikom, čimbenike odjeka (IF, Impact factor, odnosno SJR, SCImago Journal Rank Indicator) znanstvenih časopisa, citiranost radova i druge bibliometrijske podatke propisane odredbama Pravilnika.

U sadržaj obveznog podneska ulazi i potvrda knjižnice o bibliometrijskim pokazateljima radova pristupnika, dok je obvezni privitak broj 5 Potvrda Središnje knjižnice FER-a s kategorizacijom i bibliometrijskim podacima svih kvalificirajućih radova pristupnika.

Također, Naputak o primjeni Pravilnika o nagradi „Josip Lončar“ na Sveučilištu u Zagrebu navodi kako se za Srebrnu plaketu u obzir uzimaju temeljni bibliometrijski pokazatelji o radovima predloženika, koji uključuju broj objavljenih radova, broj autora na radu i to je li predloženik prvi autor, broj citata, čimbenike odjeka časopisa u kojima autor ima objavljene radove i mjesto (rang) časopisa u području u kojem se časopis referira.

Važno je naglasiti da naputak navodi kako je za bibliometrijske podatke potrebno pismeno zamoliti Središnju knjižnicu FER-a. 


\section{Bibliometrijske usluge Središnje knjižnice FER-a}

Fakultet elektrotehnike i računarstva Sveučilišta u Zagrebu (FER) broji 570 zaposlenih, od kojih stotinjak spada u administrativno osoblje, a ostatak čini znanstveno-nastavno osoblje. FER se sastoji od dvanaest zavoda koji su jezgra nastavnoga, istraživačkoga i znanstvenoga rada na pojedinome području ili grani. Također, na Fakultetu prosječno svake akademske godine studira više od tri tisuće studenata, koji uz prethodno spomenute zaposlenike čine potencijalne korisnike bibliometrijskih usluga. Pravilnik o radu Središnje knjižnice u članku 3 definira Središnju knjižnicu kao

„specijalnu i znanstvenu visokoškolsku knjižnicu usmjerenu potrebama nastavnoga, znanstvenoistraživačkoga te stručnoga rada Fakulteta, ali i svih zaposlenika u znanstvenim poljima elektrotehnike, računarstva, temeljnim tehničkim znanostima i odgovarajućim osnovama polja matematike i fizike u području prirodnih znanosti te ostalim znanstvenim područjima u skladu s potrebama Fakulteta.“

Središnja knjižnica kao ustrojbena jedinica Fakulteta djeluje s temeljnom svrhom unapređenja i potpomaganja obrazovnog, stručnog i znanstvenog rada, prvenstveno u području tehničkih znanosti, ali u svom radu zadire i u ostala znanstvena područja zbog interdisciplinarne naravi djelovanja Fakulteta.

Središnja knjižnica Fakulteta elektrotehnike i računarstva u Zagrebu ima razrađen model bibliometrijskih usluga za korisnike - u prvom redu za znanstveno-nastavno osoblje Fakulteta, ali često i za širu hrvatsku akademsku zajednicu - koji uključuje praćenje znanstvene produktivnosti Fakulteta, kvantitativnog vrednovanja znanstvenika te zastupljenosti i citiranosti znanstvenih časopisa. U tu svrhu Središnja knjižnica izdaje potvrde koje će prikazati sve kvantitativne mjeritelje uspješnosti institucije, znanstvenika ili časopisa. Od ukupno pet zaposlenih knjižničara, dva diplomirana knjižničara rade kao stručnjaci za bibliometriju.

Također, praćenjem publicistike matične ustanove kontinuirano se vrednuje znanstvena produktivnost za potrebe reakreditacije Fakulteta. To podrazumijeva kontinuirano praćenje ukupne znanstvene produktivnosti djelatnika i izdavačke djelatnosti Fakulteta (omeđenih publikacija, serijskih publikacija, znanstvenih članaka te konferencijskih radova) u svrhu provođenja postupka reakreditacije Fakulteta, unutarnje prosudbe Fakulteta, za potrebe izvještaja MZOŠ-u, na zahtjev Uprave Fakulteta i sl.

Djelatnici stručnjaci za bibliometriju upoznati su sa znanstvenom komunikacijom, sustavom i uvjetima napredovanja te znanstvenom djelatnošću na Fakultetu, kao i sa zakonskim propisima koji pokrivaju područje bibliometrije. Uspostavljena je i dobra komunikacija s korisnicima i članovima fakultetskih stručnih tijela te uredništvima časopisa (npr. CIT. Journal of Computing and Information Techno- 
logy, Automatika, Journal of Imaging Science and Technology i Digital Creativity) za čije potrebe Središnja knjižnica izdaje potvrde i izvještaje o znanstvenoj produktivnosti. Iako se komunikacija temelji prvenstveno na komuniciranju putem e-pošte, korisnici će u pravilu rado osobno preuzeti potvrdu, zatražiti pojašnjenje i dodatne informacije. Pritom se ističe važnost individualnog pristupa svakom korisniku i njegovim potrebama, kao i edukaciji korisnika.

\subsection{Začeci i razvoj usluge Središnje knjižnice FER-a}

Od 2006. godine u Središnjoj su knjižnici zabilježeni samo sporadični zahtjevi za bibliometrijskim uslugama. Radilo se uglavnom o pojedinačnim upitima na osobni zahtjev znanstvenika koji su tražili pomoć knjižničara, i to više u obliku savjetovanja, edukacije i povremenih ispisa kvantitativnih pokazatelja njihove znanstvene produktivnosti. Promjena u vidu potražnje za bibliometrijskim uslugama vidljiva je 2014. godine, kada se Središnjoj knjižnici obraća Povjerenstvo za nagrade FER-a te ju uključuje u sam proces vrednovanja kandidata i provjere kriterija. Već sljedeće godine uredništva znanstvenih časopisa iz područja elektrotehnike i računarstva traže od Središnje knjižnice potvrde o zastupljenosti časopisa za potrebe ostvarivanja prava na financijsku potporu znanstvenim časopisima od strane Ministarstva znanosti, obrazovanja i sporta. Također, znanstveno-nastavno osoblje od 2015. godine nadalje u sve većem broju počinje koristiti bibliometrijske usluge za potrebe izbora u viša zvanja i sl. Od 2017. godine Središnja je knjižnica sustavno uključena u proces evaluacije djelatnika i studenata predloženika za nagrade, u suradnji s Povjerenstvom za nagrade; formalno je uključena u proces vrednovanja kandidata za znanstveno i akademsko napredovanje u suradnji s Odborom za izbore u zvanja te Matičnim odborom za polja elektrotehnike i računarstva. Potvrda Središnje knjižnice standardizirana je te ju Matični odbor prihvaća kao važeći dokument u postupku izbora u zvanje. Nadalje, od 2018. godine dva djelatnika Središnje knjižnice postaju administratori Hrvatske znanstvene bibliografije - CROSBI u svrhu reakreditacije visokih učilišta. Administratori su dužni pregledavati $i$, po potrebi, ispravljati zapise svih djelatnika FER-a koji imaju popis radova u bazi CROSBI te pratiti publicistiku i znanstvenu produktivnost matične ustanove. Iako je primarna svrha administriranja baze CROSBI upravo priprema podataka za provođenje postupka reakreditacije, uredni zapisi služe kao temelj za kvalitetnu bibliometrijsku uslugu Središnje knjižnice. Također, uloga je administratora poticati znanstveno-nastavno osoblje da redovito unosi sve podatke $u$ bazu te ga educirati o tome kako podatke unositi na ispravan način.

Dobra praksa suradnje s uredništvima znanstvenih časopisa iz područja elektrotehnike i računarstva započela je 2011. godine i nastavila se sve do danas praćenje, izrada analiza i izvještaja vezanih uz metričke i bibliometrijske pokazatelje časopisa te izdavanje potvrda za potrebe ostvarivanja prava na financijsku 
potporu znanstvenim časopisima od strane Ministarstva znanosti, obrazovanja i sporta. Središnja knjižnica pritom zagovara važnost bibliometrije i njezinu ulogu $\mathrm{u}$ pozicioniranju znanstvenih časopisa $\mathrm{u}$ akademskoj zajednici $\mathrm{s}$ ciljem kontinuiranog praćenja i evaluiranja svih bibliometrijskih pokazatelja relevantnih za znanstveno područje koje časopis pokriva, a tako i za njegov odjek u znanstvenoj zajednici.

\subsubsection{Izbori u zvanja}

Izbori u znanstvena zvanja regulirani su Pravilnikom o uvjetima za izbor u znanstvena zvanja iz 2017. godine, dok se za izbor u znanstveno zvanje znanstveni suradnik još uvijek koristi Pravilnikom o uvjetima za izbor u znanstvena zvanja iz 2005. godine (Pravilnik je važeći 30 mjeseci nakon dana stupanja na snagu novog pravilnika). Pravilnici se međusobno razlikuju u uvjetima koje određuju i djelomično u označavanju različitih kategorija radova. Metoda izrade i izgled bibliometrijske potvrde u osnovi su prilagođeni tako da se iz njih mogu iščitati podaci za oba pravilnika, ali su prvenstveno orijentirani na novi (što je na potvrdi i naglašeno) te će se i opis postupka temeljiti na njemu. Molbe za izdavanje bibliometrijskih potvrda zaprimaju se putem e-pošte i svi korisnici dužni su molbi priložiti popis radova ili poveznicu na svoj profil u bazi CROSBI (ukoliko su podaci ažurni) kako bi se ubrzao postupak i izbjegle pogreške.

Kada se zahtjev zaprimi, unosi se u internu bazu podataka te se pristupa pretraživanju radova. Pravilnikom je određeno da je za izbor u svako znanstveno zvanje potrebno imati određeni broj radova u kategorijama A, B i C. U radove kategorije A spadaju znanstveni radovi objavljeni u časopisima koji su indeksirani u bazi Web of Science Core Collection (WoS CC), kategoriju znanstvenih radova B čine radovi objavljeni u znanstvenim časopisima koji su indeksirani u drugim bibliografskim bazama podataka, a kategoriju $\mathrm{C}$ publicirani i izlagani znanstveni radovi s međunarodnih skupova i posteri (isključivo cjeloviti radovi, a ne samo sažeci ili prezentacije). Ukoliko kandidat ima barem jedan rad kategorije A više od zadanog minimuma (zadani minimum iznosi 2 rada za znanstveno zvanje znanstveni suradnik, 3 rada za znanstveno zvanje viši znanstveni suradnik, 5 radova za znanstveno zvanje znanstveni savjetnik i 7 radova za znanstveno zvanje znanstveni savjetnik - trajno zvanje), nije potrebno zadovoljiti kriterij bodovanja na temelju kategorija $\mathrm{B}$ i C, a isto vrijedi i za kategoriju B.

Budući da je Pravilnik u nekim svojim dijelovima nedorečen, prilikom izrade bibliometrijskih potvrda cilj je prikazati što više bibliografskih podataka kako bi povjerenstva koja procjenjuju kandidate imala što potpuniji uvid. Iz tog razloga Središnja knjižnica FER-a u svakoj potvrdi donosi podatke i za bazu WoS CC i za bazu Scopus, koja je druga najrelevantnija citatna baza, čak i u slučajevima kada to ne bi bilo potrebno zbog dovoljnog broja radova iz kategorije A. Zbog toga na svakoj potvrdi uz osnovne bibliografske podatke (autori, naslov rada, naziv 
časopisa, godina objave rada) donosimo i sljedeće podatke za znanstvene radove pojedinog autora:

- ukupan broj radova i ukupan broj citata u bazi WoS CC te h-indeks

- broj znanstvenih radova u časopisima u bazi WoS CC (A kategorija) i njihovih citata te h-indeks

- ukupan broj radova i ukupan broj citata u bazi Scopus te h-indeks

- broj znanstvenih radova u časopisima u bazi Scopus (kategorija B) i njihovih citata te h-indeks

- broj znanstvenih radova s međunarodnih skupova i postera (C kategorija).

Broj citata i h-indeks navedeni su u potvrdi iako Pravilnikom nisu izričito zatraženi. Ukoliko je potrebno dodatno tražiti radove iz kategorije B i C izvan baze Scopus, pretražuju se i bibliografske baze podataka s popisa koji donosi Pravilnik o uvjetima za izbor u znanstvena zvanja iz 2005. godine te druge baze relevantne za područje tehničkih znanosti (npr. IEEE Xplore Digital Library).

Budući da se u svakoj potvrdi donose bibliometrijski podaci o svim indeksiranim radovima određenog autora, prilikom pretraživanja baze WoS CC pretražuju se svi citatni indeksi koji su dostupni hrvatskoj akademskoj zajednici radi provjere citiranosti indeksiranih radova. Sljedeći je korak filtriranje onih radova koji pripadaju kategoriji A i radi se dodatna analiza samo za njih. Pretraživanje baze provodi se po prezimenu i imenu autora, a dobiveni rezultati uspoređuju se s priloženom bibliografijom te se po potrebi dodatno traže radovi iz nje koji iz nekog razloga nisu pronađeni. To se događa veoma rijetko (npr. zbog pogreške prilikom unosa u bazu), ali ukazuje na važnost bibliografija koje autori prilažu zahtjevu. Ovdje treba naglasiti da se u obzir uzimaju i radovi koji se još ne vide u bazama jer su nedavno objavljeni te radovi koji su prihvaćeni za objavljivanje i dodijeljen im je DOI (naravno, pod uvjetom da su njihovi časopisi indeksirani u bazama). Takvi se radovi na potvrdi označavaju napomenom.

Rezultate pretraživanja moguće je sačuvati u obliku liste, koju je moguće preuzeti i pohraniti na računalo u više različitih formata i s različitim opsegom bibliografskih podataka. Takve liste radova ispisuju se u okviru WoS CC-a s dodatnim ključnim podacima koje su važni izbornim komisijama prilikom procjene relevantnosti radova (sažetak, broj citata, vrsta rada, ključne riječi, kategorije Web of Science) te se prilažu potvrdi.

Isti postupak ponavlja se i za bazu Scopus, $s$ tim da se na potvrdi naglašava koji se radovi nalaze samo u bazi Scopus (kategorija B), a koji se nalaze u obje baze. Generalno, većina autora ima više radova u bazi Scopus nego u bazi WoS CC (često se svi radovi koju su u bazi WoS CC nalaze i u bazi Scopus) i veoma su rijetki drugi slučajevi. Razlog tomu jest činjenica da su kriteriji za uvrštavanje časopisa u bazu Scopus znatno niži od onih za WoS. 
Kako je broj zahtjeva koje Knjižnica može zaprimiti u nekom razdoblju nepredvidiv, od samog početka bila je uočena potreba za automatizacijom ispisa Potvrde kao prilagodljivog izvješća - ovisno od predmetu zahtjeva, traženim bibliometrijskim pokazateljima, odgovarajućim pravilnicima, odnosno dokumentima kojima se određuju parametri ispisa. Na tom tragu podaci zahtjeva organizirani su u Microsoft Accessovoj bazi podataka, a programska logika potrebna ispisima ostvarena je unutar platforme KNIME. Program je u fazi razvoja, a cilj mu je postići potpunu automatizaciju u izradi Potvrde.

Budući da Pravilnik za određena zvanja zahtijeva određeni broj radova kojima je kandidat glavni autor te specificira autorski doprinos s obzirom na broj autora rada, na Potvrdi se nalazi i tablica u kojoj je naveden autorski doprinos za svaki rad i pozicija autora, iako taj podatak ne mora biti relevantan, s obzirom na to da Pravilnik definira kako je ,glavni autor znanstvenog rada onaj koji je nositelj problematike ili autor koji je najviše pridonio rješavanju konkretnog problema“ , a to utvrđuje stručno povjerenstvo na temelju podneska pristupnika.

Nakon analize radova, slijedi analiza časopisa u kojima su radovi objavljeni. Dva najvažnija mjerila prema kojima se ocjenjuju časopisi jesu čimbenik odjeka časopisa (engl. impact factor) i kvartili (engl. quartiles). Pravilnik specificira da se „kvartili određuju prema, za pristupnika povoljnijoj klasifikaciji, u pripadnim kategorijama JCR (Journal Citation Report) temeljenim na Web of Science bazi ili kategorijama SJR (SCIMAGO) temeljenim na SCOPUS bazi“. Tako sročen, Pravilnik ostavlja nekoliko nedoumica s kojima se kandidati i povjerenstva susreću. Kao prvo, nije određeno je li nužno odabrati kvartile samo prema JCR-u ili samo prema SJR-u ili je moguće za svaki pojedini časopis birati bolju klasifikaciju. Kao drugo, JCR i SJR često ni nemaju iste kategorije za iste časopise, a Pravilnik se može protumačiti na način da dopušta odabir najbolje kategorije unutar klasifikacije JCR ili SJR. Naime mnogi časopisi pokrivaju više kategorija i ponekad nemaju iste kvartile za sve svoje kategorije. Uz to, Pravilnik određuje da se „kvartili određuju prema godini objave rada ili zadnjoj godini za koju je poznat podatak o kvartilu časopisa, koristeći također povoljniji izbor za pristupnika“. Zbog toga se na potvrdi nalaze i sve kategorije časopisa prema bazi JCR s posebno naglašenim podacima za godinu u kojoj je rad objavljen. Dodatni problem nastaje s radovima koji su u časopisima koji se nalaze u citatnom indeksu Emerging Sources Citation Index (ESCI). ESCI izdaje tvrtka Clarivate Analytics i ona sadrži časopise koji su tek u postupku procjene kvalitete te još nemaju pokazatelje u bazi JCR - za njih se tek treba odlučiti jesu li dovoljno kvalitetni da bi u budućnosti bili uvršteni u citatne indekse. Međutim ona je dio WoS CC-a (ukoliko se posebno ne isključi, automatski se pretražuje prilikom pretrage WoS CC-a) i prema tome radovi u njoj računaju se kao radovi kategorije A. Pravilnikom se specificira: ,ako je časopis u kojem je rad objavljen indeksiran u WoS CC-u, ali mu još nije određen kvartil i/ili čimbenik odjeka, smatrat će se da je razvrstan u četvrti kvartil (Q4)“ 
, ali baza ESCI ipak je u tom kontekstu specifičan slučaj koji nije dovoljno precizno riješen, pa se radovi indeksirani u toj bazi u potvrdi posebno naglašavaju.

Iako Pravilnik određuje da su kod časopisa bitni samo kvartili, Središnja knjižnica na svojim potvrdama donosi i podatak o čimbeniku odjeka časopisa, i to prema bazama JCR i SJR. Primjer naslovne stranice potvrde može se vidjeti na slici 1.
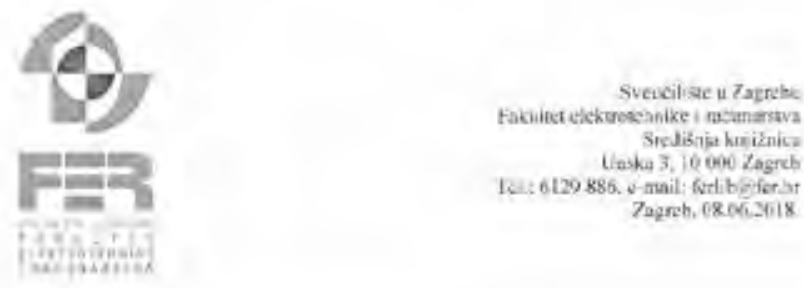

\section{WOURDSOIXDEKSLRAVOSTI CITBAVOSTI ZNANSTVENIH RABOVA U} RELEVANTNIVI BAZAMIA PODATAKA

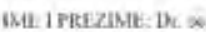

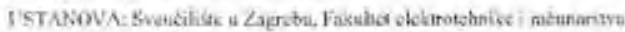

SVRHA bmor L manusvero-nastavas avanje

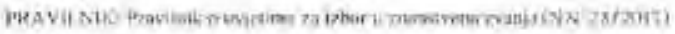

\section{INDTKSIR NNOST RATXVA}

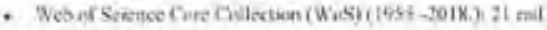

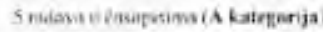

- Scophes 79 tama

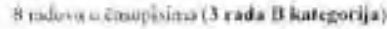

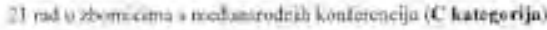

\section{CHIRAMUKI RAINAYA}

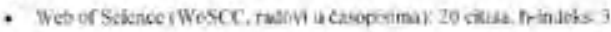

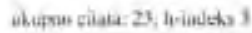

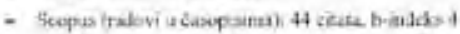
alupte eliacs rak, h-itabos ?

FEOE! RADOVA POKV NTTLIMA
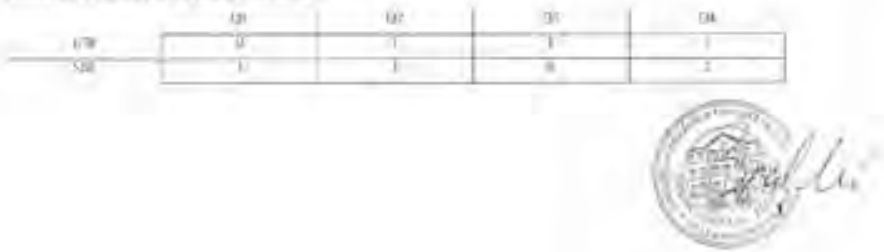

Slika 1. Primjer potvrde s bibliometrijskim pokazateljima za izbor u znanstvena zvanja 


\subsubsection{Nagrade}

Prema uputi Povjerenstva za dodjelu nagrada, Središnja knjižnica dostavlja bibliometrijske pokazatelje u obliku Excelove tablice. Tablica se sastoji od dva osnovna dijela: dio s detaljnim pregledom za svakog pojedinog kandidata (tablica 1) te dio sa skupnim podacima za sve kandidate (tablica 2). Za svakog kandidata donosi se popis radova sa sljedećim podacima: autor(i), pozicija autora, naslov rada, naziv časopisa u kojemu je objavljen i njegov ISSN, godina objavljivanja, čimbenik odjeka i kvartili prema bazama JCR i SJR (daju se kvartili za svaku pojedinu kategoriju časopisa u godini objave rada) te broj citata u bazama WoS CC i Scopus (ukupan broj te za svaki pojedini rad). 
Tablica 1. Primjer bibliometrijskih podataka za autora

\begin{tabular}{|c|c|c|c|c|c|c|}
\hline Autor(i) & $\begin{array}{l}\text { Autor } \\
\text { pozicija } \\
\text { / autori } \\
\text { sum }\end{array}$ & $\begin{array}{l}\text { Naslov } \\
\text { rada }\end{array}$ & $\begin{array}{l}\text { Časopis } \\
\text { naziv }\end{array}$ & $\begin{array}{l}\text { Časopis } \\
\text { ISSN }\end{array}$ & $\begin{array}{l}\text { Godi- } \\
\text { na }\end{array}$ & $\begin{array}{c}\text { Publikacija } \\
\text { kategorija JCR }\end{array}$ \\
\hline $\begin{array}{l}\text { Autor, Au- } \\
\text { tor, Autor, } \\
\text { Autor }\end{array}$ & $3 / 4$ & $\begin{array}{l}\text { Znanstveni } \\
\operatorname{rad} 1\end{array}$ & $\begin{array}{l}\text { IEEE TRAN- } \\
\text { SACTIONS ON } \\
\text { INDUSTRIAL } \\
\text { ELECTRONICS }\end{array}$ & $\begin{array}{l}0278- \\
0046\end{array}$ & 2012 & $\begin{array}{l}\text { ENGINEERING, ELE- } \\
\text { CTRICAL \& ELECTRO- } \\
\text { NIC | AUTOMATION \& } \\
\text { CONTROL SYSTEMS | } \\
\text { INSTRUMENTS \& IN- } \\
\text { STRUMENTATION }\end{array}$ \\
\hline $\begin{array}{l}\text { Autor, Au- } \\
\text { tor, Autor, } \\
\text { Autor, } \\
\text { Autor }\end{array}$ & $2 / 5$ & $\begin{array}{c}\text { Znanstveni } \\
\operatorname{rad} 2\end{array}$ & $\begin{array}{l}\text { IEEE TRAN- } \\
\text { SACTIONS ON } \\
\text { POWER ELE- } \\
\text { CTRONICS }\end{array}$ & $\begin{array}{l}0885- \\
8993\end{array}$ & 2012 & $\begin{array}{l}\text { ENGINEERING, ELE- } \\
\text { CTRICAL \& ELECTRO- } \\
\text { NIC }\end{array}$ \\
\hline $\begin{array}{l}\text { Autor, Au- } \\
\text { tor, Autor }\end{array}$ & $3 / 3$ & $\begin{array}{c}\text { Znanstveni } \\
\operatorname{rad} 3\end{array}$ & $\begin{array}{l}\text { IEEE TRAN- } \\
\text { SACTIONS ON } \\
\text { ENERGY CON- } \\
\text { VERSION }\end{array}$ & $\begin{array}{l}0885- \\
8969\end{array}$ & 2016 & $\begin{array}{c}\text { ENGINEERING, } \\
\text { ELECTRICAL \& ELE- } \\
\text { CTRONIC | ENERGY \& } \\
\text { FUELS }\end{array}$ \\
\hline $\begin{array}{l}\text { Autor, Au- } \\
\text { tor, Autor, } \\
\text { Autor }\end{array}$ & $3 / 4$ & $\begin{array}{c}\text { Znanstveni } \\
\operatorname{rad} 4\end{array}$ & $\begin{array}{l}\text { IEEE TRAN- } \\
\text { SACTIONS ON } \\
\text { ELECTROMA- } \\
\text { GNETIC CAPA- } \\
\text { BILITY }\end{array}$ & $\begin{array}{l}0018- \\
9375\end{array}$ & 2015 & $\begin{array}{c}\text { ENGINEERING, ELE- } \\
\text { CTRICAL \& ELECTRO- } \\
\text { NIC | TELECOMMUNI- } \\
\text { CATIONS }\end{array}$ \\
\hline $\begin{array}{l}\text { Autor, Au- } \\
\text { tor, Autor }\end{array}$ & $3 / 3$ & $\begin{array}{l}\text { Znanstveni } \\
\text { rad } 5\end{array}$ & $\begin{array}{l}\text { ELEKTRONIKA } \\
\text { IR ELEKTROTE- } \\
\text { CHNIKA }\end{array}$ & $\begin{array}{l}1392- \\
1215\end{array}$ & 2014 & $\begin{array}{l}\text { ENGINEERING, ELE- } \\
\text { CTRICAL \& ELECTRO- } \\
\text { NIC }\end{array}$ \\
\hline $\begin{array}{l}\text { Autor, Au- } \\
\text { tor, Autor, } \\
\text { Autor, } \\
\text { Autor, } \\
\text { Autor }\end{array}$ & $6 / 6$ & $\begin{array}{l}\text { Znanstveni } \\
\operatorname{rad} 6\end{array}$ & $\begin{array}{l}\text { IEEE TRAN- } \\
\text { SACTIONS ON } \\
\text { INDUSTRIAL } \\
\text { ELECTRONICS }\end{array}$ & $\begin{array}{c}0278- \\
0046\end{array}$ & 2017 & $\begin{array}{c}\text { AUTOMATION \& } \\
\text { CONTROL SYSTEMS | } \\
\text { ENGINEERING, ELE- } \\
\text { CTRICAL \& ELECTRO- } \\
\text { NIC | INSTRUMENTS \& } \\
\text { INSTRUMENTATION }\end{array}$ \\
\hline $\begin{array}{l}\text { Autor, Au- } \\
\text { tor, Autor }\end{array}$ & $1 / 3$ & $\begin{array}{l}\text { Znanstveni } \\
\operatorname{rad} 7\end{array}$ & $\begin{array}{l}\text { IET ELECTRIC } \\
\text { POWER APPLI- } \\
\text { CATIONS }\end{array}$ & $\begin{array}{l}1751- \\
8660\end{array}$ & 2014 & $\begin{array}{l}\text { ENGINEERING, ELE- } \\
\text { CTRICAL \& ELECTRO- } \\
\text { NIC }\end{array}$ \\
\hline Total & & 7 & & & & \\
\hline
\end{tabular}




$\begin{array}{ccccccc}\text { JCR IF } & \begin{array}{l}\text { JCR } \\ \text { kvartil } \\ \max \end{array} & \begin{array}{c}\text { WoS } \\ \text { citati }\end{array} & \begin{array}{c}\text { Publikacija } \\ \text { kategorija SJR }\end{array} & \text { SJR IF } & \begin{array}{c}\text { SJR } \\ \text { kvartil } \\ \max \end{array} & \begin{array}{c}\text { SCO- } \\ \text { PUS } \\ \text { citati }\end{array}\end{array}$

\begin{tabular}{|c|c|c|c|c|c|}
\hline $\begin{array}{c}5.165 \\
\text { (JCR2012) }\end{array}$ & $\begin{array}{c}\text { Q1 } \\
\text { (JCR2012) }\end{array}$ & 26 & $\begin{array}{l}\text { Computer Science Appli- } \\
\text { cations | Control and } \\
\text { Systems Engineering | } \\
\text { Electrical and Electronic } \\
\text { Engineering }\end{array}$ & $\begin{array}{c}2.198 \\
\text { (SJR2012) }\end{array}$ & $\begin{array}{c}\text { Q1 } \\
\text { (SJR2012) }\end{array}$ \\
\hline
\end{tabular}

$\begin{array}{ccccccc}4.08 & \text { Q1 } & 17 & \text { Electrical and Electronic } & 1.945 & \text { Q1 } & 22 \\ (\text { JCR2012) } & \text { (JCR2012) } & & \text { Engineering } & \text { (SJR2012) } & \text { (SJR2012) } & 2\end{array}$

\begin{tabular}{ccccc}
\multicolumn{5}{c}{ Electrical and Electronic } \\
3.808 & Q1 & Engineering | Energy & 1.524 & Q1 \\
$($ JCR2016) & (JCR2016) & 4 & Engineering and Power & Technology \\
& & & (SJR2016) & (SJR2016)
\end{tabular}

Atomic and Molecular

$\begin{array}{cccccc}1.146 & \text { Q2 } & \text { Physics, and Optics } \mid & 1.013 & \text { Q1 } \\ (\text { Condensed Matter Physi- } & \begin{array}{c}\text { Co15) } \\ \text { cs Electrical and Ele- } \\ \text { ctronic Engineering }\end{array} & \text { (JCR2015) } & \text { (SJR2015) } & & \\ \text { (SJR2015) }\end{array}$

\begin{tabular}{|c|c|c|c|c|c|c|}
\hline $\begin{array}{c}0.561 \\
\text { (JCR2014) }\end{array}$ & $\begin{array}{c}\text { Q4 } \\
\text { (JCR2014) }\end{array}$ & 3 & $\begin{array}{l}\text { Electrical and Electronic } \\
\text { Engineering }\end{array}$ & $\begin{array}{c}0.292 \\
(\mathrm{SJR} 2014)\end{array}$ & $\begin{array}{c}\text { Q2 } \\
\text { (SJR2014) }\end{array}$ & 2 \\
\hline
\end{tabular}

\begin{tabular}{|c|c|c|c|c|c|c|}
\hline $\begin{array}{c}7.168 \\
(\mathrm{JCR} 2016)\end{array}$ & $\begin{array}{c}\text { Q1 } \\
\text { (JCR2016) }\end{array}$ & 0 & $\begin{array}{l}\text { Computer Science Appli- } \\
\text { cations | Control and } \\
\text { Systems Engineering | } \\
\text { Electrical and Electronic } \\
\text { Engineering }\end{array}$ & $\begin{array}{c}2.742 \\
(\mathrm{SJR} 2016)\end{array}$ & $\begin{array}{c}\text { Q1 } \\
\text { (SJR2016) }\end{array}$ & 0 \\
\hline \multirow[t]{2}{*}{$\begin{array}{c}1.211 \\
(\text { JCR2014) }\end{array}$} & $\begin{array}{c}\text { Q3 } \\
\text { (JCR2014) }\end{array}$ & 0 & $\begin{array}{l}\text { Electrical and Electronic } \\
\text { Engineering }\end{array}$ & $\begin{array}{c}0.672 \\
(\mathrm{SJR} 2014)\end{array}$ & $\begin{array}{c}\text { Q1 } \\
\text { (SJR2014) }\end{array}$ & 0 \\
\hline & & 52 & & & & 66 \\
\hline
\end{tabular}


Vjesnik bibliotekara Hrvatske 62, 1(2019), 341-362

Tablica 2. Skupni prikaz podataka za sve kandidate

\begin{tabular}{|c|c|c|c|c|c|c|c|c|}
\hline $\begin{array}{c}\text { Kandi- } \\
\text { dat }\end{array}$ & $\begin{array}{c}\text { Ukupno } \\
\text { radova } \\
\text { indeksiranih } \\
\text { u bazi } \\
\text { SCOPUS }\end{array}$ & $\begin{array}{c}\text { Ukupno } \\
\text { radova } \\
\text { indeksiranih } \\
\text { u bazi } \\
\text { WOSCC }\end{array}$ & $\begin{array}{c}\text { Radova u } \\
\text { časopisima } \\
\text { Scopus | } \\
\text { WoSCC }\end{array}$ & $\begin{array}{l}\text { 1. autor u } \\
\text { časopisi- } \\
\text { ma }\end{array}$ & $\begin{array}{c}\text { Max } \\
\text { IF } \\
\text { JCR }\end{array}$ & $\begin{array}{l}\text { Max } \\
\text { IF } \\
\text { SJR }\end{array}$ & $\begin{array}{l}\text { Q1 } \\
\text { JCR - } \\
\text { SJR }\end{array}$ & $\begin{array}{l}\text { Q2 } \\
\text { JCR - } \\
\text { SJR }\end{array}$ \\
\hline Autor 1 & 16 & 13 & 5 | 4 & 3 & 5.541 & 4.172 & $1 / 4$ & $3 / 1$ \\
\hline Autor 2 & 18 & 14 & $7 \mid 7$ & 0 & 7.168 & 2.742 & $4 / 6$ & $1 / 1$ \\
\hline Autor 3 & 4 & 3 & $2 \mid 1$ & 2 & 3.289 & 1.562 & $1 / 2$ & $1 / 0$ \\
\hline Autor 4 & 7 & 7 & $2 \mid 1$ & 1 & 0.987 & 0.364 & $-/-$ & $-/-$ \\
\hline Autor 5 & 16 & 14 & $5 \mid 5$ & 2 & 7.168 & 2.742 & $4 / 7$ & $3 / 0$ \\
\hline Autor 6 & 3 & 3 & $2 \mid 2$ & 1 & 0.573 & 0.299 & $-/-$ & $0 / 1$ \\
\hline Autor 7 & 4 & 4 & $1 \mid 1$ & 1 & 2.957 & 1.362 & $1 / 1$ & $-/-$ \\
\hline
\end{tabular}




\begin{tabular}{|c|c|c|c|c|c|c|c|c|c|}
\hline $\begin{array}{c}\text { Q3 } \\
\text { JCR } \\
\text {-SJR }\end{array}$ & $\begin{array}{c}\text { Q4 } \\
\text { JCR } \\
- \\
\text { SJR }\end{array}$ & $\begin{array}{c}\text { h-idex } \\
\text { - svi } \\
\text { radovi } \\
\text { SCOPUS }\end{array}$ & $\begin{array}{c}\text { h-indeks } \\
\text { - svi } \\
\text { radovi } \\
\text { WOSCC }\end{array}$ & $\begin{array}{l}\text { h-index - } \\
\text { radovi u } \\
\text { časopisu } \\
\text { SCOPUS }\end{array}$ & $\begin{array}{c}\text { h-indeks } \\
\text { - radovi } \\
\text { u časo- } \\
\text { pisu } \\
\text { WOSCC }\end{array}$ & $\begin{array}{l}\text { SCOPUS } \\
\text { citati } \\
\text { (svi rado- } \\
\text { vi) }\end{array}$ & $\begin{array}{l}\text { WOS- } \\
\text { CC } \\
\text { citati } \\
\text { (svi } \\
\text { radovi) }\end{array}$ & $\begin{array}{l}\text { SCOPUS } \\
\text { citati } \\
\text { radovi u } \\
\text { časopisi- } \\
\text { ma }\end{array}$ & $\begin{array}{l}\text { WOSCC } \\
\text { citati } \\
\text { radovi u } \\
\text { časopisi- } \\
\text { ma }\end{array}$ \\
\hline $1 / 0$ & $-/-$ & 4 & 2 & 3 & 2 & 35 & 16 & 15 & 12 \\
\hline $1 / 0$ & $1 / 0$ & 4 & 3 & 3 & 3 & 81 & 60 & 66 & 52 \\
\hline$-/-$ & $-/-$ & 2 & 1 & 2 & 1 & 6 & 3 & 2 & 1 \\
\hline $1 / 2$ & $1 / 0$ & 2 & 2 & 1 & 1 & 14 & 7 & 4 & 4 \\
\hline$-/-$ & $-/-$ & 4 & 2 & 3 & 2 & 89 & 52 & 27 & 47 \\
\hline $0 / 1$ & $2 / 0$ & 1 & 1 & 1 & 1 & 2 & 2 & 2 & 2 \\
\hline$-/-$ & $-/-$ & 1 & 1 & 0 & 0 & 3 & 3 & 0 & 0 \\
\hline
\end{tabular}


U skupnom prikazu za sve kandidate (tablica 3 ) prikazani su sažeti podaci: broj svih indeksiranih radova u bazama WoS CC i Scopus, broj radova u časopisima u bazama WoS CC i Scopus, broj radova kojima je kandidat prvi autor, najviši čimbenici odjeka prema bazama JCR i SJR, broj radova po kvartilima prema bazama JCR i SJR, h-indeks za sve indeksirane radove, h-indeks za radove u časopisima, broj citata za sve radove u bazama WoS CC i Scopus te broj citata za radove u časopisima u bazama WoS CC i Scopus. Kao dio Excelova dokumenta uvršteni su i podaci koji su preuzeti i sačuvani u obliku lista iz baza WoS CC i Scopus, a mnogi podaci koji se donose u tablicama zapravo su automatski generirani iz tih podataka. Na taj način ubrzava se cijeli postupak, a i izbjegava se mogućnost pogreške koja postoji kod ručnog upisivanja podataka te se istovremeno omogućuje brzo i jednostavno generiranje bilo kojeg novog seta podataka ukoliko je to povjerenstvu potrebno prilikom donošenja odluke.

U oba slučaja kada Središnja knjižnica izdaje Potvrde s kategorizacijom i bibliometrijskim podacima svih kvalificirajućih radova pristupnika (kod izbora u znanstvena zvanja i kod procjene kandidata za nagrade), vodi se idejom da je poželjno donijeti što je moguće veću količinu podataka, kako bi povjerenstva imala što potpuniju sliku prilikom donošenja svojih odluka. Da bi se to što učinkovitije postiglo, cijeli se postupak pokušava automatizirati što je više moguće, a to je omogućeno zahvaljujući listama s podacima koji se mogu preuzeti i pohraniti na računalo te učitavanjem tih lista u naš program.

\subsubsection{Statistički pokazatelji bibliometrijskih zahtjeva}

U tablici 3 prikazan je ukupan broj zahtjeva u navedenom razdoblju uz dodatnu podjelu prema svrhama bibliometrijskih zahtjeva upućenih Središnjoj knjižnici FER-a. Tako je u razdoblju od 1. srpnja 2017. do 1. srpnja 2018. evidentirano ukupno 108 zahtjeva, od čega je 68 izdano u svrhu izbora u zvanja, 22 u svrhu dodjeljivanja fakultetskih nagrada, a 18 zahtjeva iz ostalih razloga, kao što je izrada bibliometrijskih pokazatelja na zahtjev određenog uredništva znanstvenog časopisa, informativni upiti i sl.

Tablica 3. Zahtjevi u razdoblju od 1. 7. 2017. do 1. 7. 2018.

\begin{tabular}{|l|c|}
\hline Svrha zahtjeva & Broj zahtjeva \\
\hline Izbori u zvanja & 68 \\
\hline Fakultetske nagrade & 22 \\
\hline Ostalo & 18 \\
\hline Ukupno & 108 \\
\hline
\end{tabular}

Kako su se bibliometrijske usluge Središnje knjižnice FER-a postupno razvijale u opsegu i kvaliteti, tako ih je i šira znanstvena zajednica počela prepoznavati 
kao kvalitetan i pouzdan izvor informacija, pa su tako sve češći zahtjevi za izradu potvrda s bibliometrijskim podacima znanstvenika i profesora s područja tehničkih znanosti izvan FER-a. Naime Središnjoj knjižnici FER-a često se obraćaju zaposlenici s drugih visokoškolskih institucija iz Republike Hrvatske upravo zbog nepostojanja takve usluge na njihovim institucijama. Zbog dodatnog opterećenja, vjerodostojnosti same potvrde te broja radnih sati koje djelatnici utroše na svaki pojedinačni zahtjev, bibliometrijske usluge Središnje knjižnice FER-a za vanjske korisnike naplaćuju se prema Odluci o troškovima izdavanja Potvrde o bibliometrijskim pokazateljima koju je donio dekan FER-a. Prilikom izdavanja Potvrde Fakultet korisniku izdaje račun.

\section{Zaključak i preporuke za daljnji rad}

Nakon godina sporadičnog i nesustavnog djelovanja knjižničara FER-a u području bibliometrije, razvojem usluge i uspostavom dobre suradnje u matičnoj instituciji stvorilo se povjerenje u knjižničarsku struku i kompetencije knjižničara. Bibliometrijske usluge Središnje knjižnice FER-a ne predstavljaju više samo podršku znanstveno-nastavnom osoblju, već su utkane u temeljne pravne propise same institucije i kao takve postaju obvezujuće te dobivaju na značaju. I sama potvrda dobiva snagu službenog dokumenta za čiju vjerodostojnost jamče knjižničari stručnjaci za bibliometriju. Pritom je važno naglasiti koliko je važna uspostava dobre i otvorene komunikacije te profesionalna suradnja između knjižnice i radnih tijela matične ustanove, što otvara vrata knjižničarima za daljnji razvoj usluge i nove suradnje.

Sada, kada su se knjižničari FER-a počeli aktivnije uključivati u postupke akademskog napredovanja te su se svojim znanjima i vještinama nametnuli kao nezaobilazan čimbenik tog aspekta znanstvene djelatnosti, vrijeme je da se napravi korak dalje i da svojim vještinama i kompetencijama knjižničari utru put za djelovanje na još višoj razini, u smislu formalnog uključivanja u rad fakultetskih radnih tijela te sudjelovanja $u$ formiranju zakonskih propisa kojima se reguliraju uvjeti za izbor u zvanja.

\section{LITERATURA}

Bibliometrija. // Hrvatska enciklopedija, mrežno izdanje (2018). Leksikografski zavod Miroslav Krleža. [citirano: 2018-05-15]. Dostupno na: http://www.enciklopedija.hr/ natuknica.aspx?id=7462.

Garfield, E. Citation indexing: its theory and application in science, technology, and humanities. New York : Wiley, 1979.

Krajna, T. Međunarodna zapaženost hrvatskih autora s područja tehničkih znanosti (1922-2001). Zagreb: Filozofski fakultet, 2003. 
Naputak o primjeni Pravilnika o nagradi „Josip Lončar“ na Sveučilištu u Zagrebu Fakultetu elektrotehnike i računarstva: (donio dekan Fakulteta 21. ožujka 2012. godine). [citirano: 2018-05-15]. Dostupno na: https://www.fer.unizg.hr/_download/ repository/Naputak_o_primjeni_Pravilnika_o_nagradi_Josip_Loncar[1].pdf.

Obvezni sadržaj podneska za izbor u znanstveno zvanje na osobni zahtjev ili po zahtjevu znanstvene organizacije. [citirano: 2018-05-15]. Dostupno na: https://www.fer. unizg.hr/_download/repository/Zahtjev_za_znanstveno_zvanje__obvezni_sadrzaj_StariPravilnik.doc.

Otlet, P. Traité de documentation: le livre sur le livre, théorie et pratique. Mons, Belgium: Editiones Mundaneum, 1934.

Pavunić, M. Struktura i djelovanje knjižnice Elektrotehničkog fakulteta u Zagrebu. Zagreb: Prirodoslovno-matematički fakultet Sveučilišta, 1966.

Pravilnik o radu Središnje knjižnice: (donesen na 663. redovitoj sjednici Fakultetskog vijeća održanoj 21. ožujka 2012. godine). [citirano: 2018-05-15]. Dostupno na: https://www.fer.unizg.hr/_download/repository/Pravilnik_o_radu_Sredisnje_ knjiznice_2016[1].pdf.

Pravilnik o uvjetima za izbor u znanstvena zvanja. // Narodne novine 84, 1633(2005). [citirano: 2018-05-18]. Dostupno na: https://narodne-novine.nn.hr/clanci/sluzbeni/2005_07_84_1633.html.

Pravilnik o uvjetima za izbor u znanstvena zvanja. // Narodne novine 28, 652(2017). [citirano: 2018-05-18]. Dostupno na: https://narodne-novine.nn.hr/clanci/sluzbeni/ full/2017_03_28_652.html.

Pritchard, A. Statistical bibliography or bibliometrics? // Journal of Documentation 25, 4(1969), 348-349.

Profil sektora: elektrotehnika i računarstvo. Zagreb: Agencija za strukovno obrazovanje i obrazovanje odraslih, 2011. [citirano: 2018-05-22]. Dostupno na: http://www.edusinfo.hr/Appendix/DDOKU_HR/DDHR20150127N92_25_1.pdf.

Spomenica - 40. obljetnica Fakulteta elektrotehnike i računarstva: 1956.-1996. [glavni urednik Tomislav Petković]. Zagreb: Fakultet elektrotehnike i računarstva Sveučilišta, 1996.

Tehnički fakulteti 1919.-1994. : monografija u povodu 75. obljetnice osnutka tehničke visoke škole u Zagrebu. Zagreb: Sveučilište, 1994.

Zakon o znanstvenoj djelatnosti i visokom obrazovanju: pročišćeni tekst zakona: NN 123/03, 198/03, 105/04, 174/04, 02/07, 46/07, 45/09, 63/11, 94/13, 139/13, 101/14, 60/15, 131/17. // Zakon.hr: pročišćeni tekstovi zakona. [citirano: 2018-05-15]. Dostupno na: https://www.zakon.hr/z/320/Zakon-o-znanstvenoj-djelatnosti-i-visokom-obrazovanju.

Važeći akti za postupak izbora u zvanja. [citirano: 2018-05-15]. Dostupno na: https:// www.fer.unizg.hr/novosti/natjecaji/radna_mjesta\#\%23!p_rep_107492!_-15294. 